\title{
最適射影法に基づいた能動フラッタ抑止系の低次元補份器の構成*1 \\ A Synthesis of Reduced-Order Compensators for Active Flutter Suppression System \\ Based on the Optimal Projection Method
}

\author{
藤篤*2 \\ Atsushi FUJIMORI
}

Key Words : Active Flutter Suppression, Optimal Projection Method, Reduced-Order Compensator, LQG

\begin{abstract}
A synthesis of reduced-order compensators for active flutter suppression of a two-dimensional airfoil is studied using the optimal projection method. In the method, condition for minimizing a quadratic performance index is taken into consideration for a compensator whose the order is less than the order of the controlled plant. A reduced-order compensator is then constructed by satisfying the condition. In this paper, rough derivation of two modified Riccati equations and two modified Lyapunov equations as the condition are shown. Since these equations are coupled each other, it is not possible to solve them at one time. Therefore, iterative calculation methods are examined and an algorithm which improves a defect of the existing iterative method is proposed. Numerical simulations which are carried out using thirteenth-order active flutter suppression systems of a two-dimensional airfoil show that the optimal projection method can yield second-order compensators in all simulation cases, and compen. sators whose the order is six or more almost show the same control performance as the optimal observer, that is, Kalman filter.
\end{abstract}

\section{1. 序論}

航空機に発生する空力弾性問題を、制御工学を用い て解決しようとする試みは 20 年程前から行われてお り",ななかでも能動フラッタ抑止 (AFS; Active Flutter Suppression) p突風荷重軽減（GLA；Gust Load Alleviation）は，省エネルギー化，飛行性能の向上， 耐疲労性向上に伴う航空機の寿命の延長などのメリッ トをもたらす技術として注目されている。これらの問 題に関し，最近の制御システムの構成は二次形式ガウ

\footnotetext{
*! 平成 2 年 1 月 10 日原稿受理

*2 静岡大学工学部エネルギー機械工学科
}

又雑音問題 (LQG ; Linear Quadratic Gaussian) $に$ 㷌着した制御系設計が主流な方法となっている。この LQG での制御系設計における問題の一つに，補償器 の低次元化がある，一般に，空力弾性系の方程式は構 造弾性モードと非定常空気力を含んた偏微分方程式で あるため，高次元系になりやすいという傾向があるー 方, LQG 理論から導かれる補偵器は制御対象の次数 と等しいものが要求され，このような高次元補償器は オンラインで制御するには非実用的である。それ故, 低次元でしかも最適な補償器と同レベルの性能を持つ 低次元補偵器を構成することは実用上有意義なことて ある.この問題に著者らは以前, 二次元翼の AFS シ ステムに対し，GHR (Generalized Hessenberg Representation) 法と NFA(Nyquist Frequency Approximation) 法の二つの低次元補偵器構成法を提案した ${ }^{22}$. GHR 法は最適オブザーバ (Kalmanフィルタ)を近似 するように低次元化を行って低次元補償器を粠成する ため，二次形式評価コストを考虑した設計法である。 しかし，補償器の十分な低次元化が可能でない場合 や，系全体の安定余裕の不足する傾问がある，一方， NFA 法は低次元でも安定余裕が十分な補偵器が構成 可能であるが，操舵量や評価コストの增大化を招き最 適性に欠ける面がある。

本論文は、これらの問題点を改善するため, AFS システムに対する低次元補償器の構成を最適射影 法3,4ににって検討する．最適射影法は，二次形式評 価コストを最小化する条件をプラントの次数以下の補 供器について考え，これを満足するように補供器を求 める方法であり，GHR 法のような近似ではない2). ただ問題は，いかにしたらその条件式を満たすような 解に辿り着けるかであり、計算方法がこの手法のポイ ントとなる。本論文ては，最適射影法にるける低次元 補償器構成に対し文献 4 に示されている計算方法に改 良を加えた計算アルコリスムを提案する。この方法を 
文献 2 と同じ二次元翼の AFS システムに適用し，得 られた制御系の性能を比較することにより本手法の有 用性を恮討する。

\section{2. 制御対象と低次元補僙器}

制御対象は，前回 ${ }^{2)}$ と同様な第 1 図に示される二次 元異を考える．翼の自由度は，基準位置からの弾性軸 (e. a.) での曲げ変位 $h$ ，振り角 $\alpha$ ，それに後縁操舵面 の舵角 $\beta$ である，空気力は，翼の運動による成分と 突風による成分があり．それらの非定常部分には有理 関数近似表現を用いる。 また，駆動系は 2 次系を，突 風モデルは1次系を仮定すると，二次元翼の AFS シ ステムの状態方程式は

$$
\begin{aligned}
& \dot{x}=A x+B u+B_{n} w_{1} \\
& y=C x+w_{2} \\
& x \in \mathcal{R}^{13}, \quad u \in \mathcal{R}^{2}, \quad w_{1} \in R^{2} \\
& y, \quad w_{2} \in \mathcal{R}^{1} \text { or } \mathbb{R}^{2}
\end{aligned}
$$

と書ける ${ }^{2)} . w_{1}, w_{2}$ は互いに無相関な白色雑音であ る. 出力 $y$ は翼の曲げ変位とその加速度を考える。

(1)式で表される制御対象に対し，次数が $n_{c}(\leqq n)$ の低次元補償器は,

$$
\begin{aligned}
& \dot{x}_{c}=A_{c} x_{c}+B_{c} y \\
& u=C_{c} x_{c} \\
& x_{c} \in Q^{n_{c}}
\end{aligned}
$$

と表される．ただし， $\left(A_{c}, B_{c}, C_{c}\right)$ は可制御，可観測 であるとし，次の二次形式評価コストを最小化する補 筫器を求めることを考える。

$$
\begin{aligned}
& J=E\left\{\lim _{T \rightarrow \infty} \frac{1}{T} \int_{0}^{T}\left(y^{T} R_{1} y+u^{T} R_{2} u\right) d t\right\} \\
& R_{1} \geqq 0, \quad R_{2}>0
\end{aligned}
$$

\section{3. 最適射影法の必要条件式}

GHR 法 ${ }^{2}$ p Yousuff $5^{5)}$, 宮沢 ${ }^{6)}$ の低次元補暴器構 成法は，最適オブザーバを、“近似”するという考え 方であるが，最適射影法では( 3 )式の $J$ を最小化す

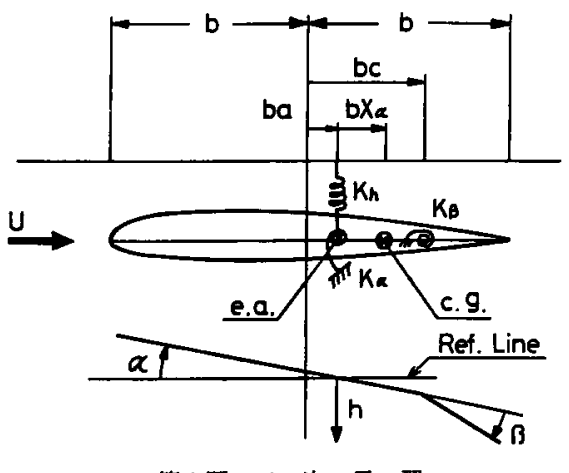

第 1 図二次 元
る必要条件式を次数が $n_{c}(\leqq n)$ の補偵器に対し導出 し、これを満たすことを考える。すなわち，ある次数 の補償器を用いた場合の最適性を考えている，その条 件式とは，二つの修正 Riccati 方程式と二つの修正 Lyapunov 方程式である。本章ては，これらの方程式 の大まかな誘導について述へる。なお，3.1節にその 誘導に必要となるいくつかの基礎知識について述べて おく.

\section{1 定童と補題}

[定義 1] 半単純 (semisimple)

行列 $A \in C^{n \times n}$ が rank $A=r(\leqq n) の と き$, 正則行 列 $S, T \in \mathcal{C}^{n \times n}$ により

$$
S A T=\operatorname{diag}\left\{\alpha_{1} \cdots a_{r} 0 \cdots 0\right\}
$$

と对角化できるとき. $A$ は半単純行列 (semisimple matrix)であるという.とくに $\alpha_{i}>0$ のとき， $A$ は正 の半単純行列(positive semisimple matrix)という.

半正定行列は，正の半単純行列である．なお，正定 行列は正の単純行列 (positive simple matrix) であ る.

[定義 2］反傾変換（contragredient transformation)

二つのエルミート行列 $A, B \in C^{n \times n}$ をある正則な 変換行列 $T \in \mathcal{C}^{n \times n}$ によって

$$
\begin{aligned}
& T^{-1} A T^{-*}=\Lambda_{A} \\
& T^{*} B T=\Lambda_{B}
\end{aligned}
$$

と同時対角化することを反傾変換 (contragredient transformation) という。ただし， $T^{*} は T$ の共役転 置行列を表し， $\Lambda_{A}, \Lambda_{B}$ は対角行列である.

[補題 1] $A, B \in \mathcal{C}^{n \times n}$ がともに半正定行列である とき， $A B$ または $B A$ は正の半単純行列であり，反 傾変換によって同時対角化できる。

[補題 2] $A, B \in \mathbb{R}^{n \times n}$ がともに半正定行列であ り, $\operatorname{rank} A=\operatorname{rank} B=\operatorname{rank} A B=r(\leqq n)$ のと，

$$
\begin{aligned}
& A B=G^{T} M F \\
& F G^{T}=I_{r}
\end{aligned}
$$

を満たす行列 $G, F \in \mathbb{R}^{r \times n}$ と正の単純行列 $M \in R^{r \times r}$ が存在する。

[補題 3] 補題 $2 の A, B, G, F$ において $\tau \triangleq G^{T} F \quad\left(\in Q^{n \times n}\right)$

なる量は次式を満たす。

$$
A=\tau A, \quad B=B \tau
$$

[補題 4] 半正定行列 $A \in \mathcal{C}^{n \times n}$ を

$$
A \triangleq\left[\begin{array}{ll}
A_{1} & A_{12} \\
A_{12}^{*} & A_{2}
\end{array}\right]
$$

と分割するとき，次式が成り立つ。 


$$
\begin{aligned}
& A_{1} \geqq 0, \quad A_{12}{ }^{*} A_{1}{ }^{+} A_{1}=A_{12}{ }^{*}, \\
& A_{2}-A_{12}{ }^{*} A_{1}{ }^{+} A_{12} \geqq 0 \\
& A_{2} \geqq 0, \quad A_{12} A_{2}{ }^{+} A_{2}=A_{12}, \\
& A_{1}-A_{12} A_{2}{ }^{+} A_{12}{ }^{*} \geqq 0
\end{aligned}
$$

ただし， $A_{1}{ }^{+}$は $A_{1}$ の擬似逆行列を表す。とくに， rank $A=\operatorname{rank} A_{1}$ または $\operatorname{rank} A=\operatorname{rank} A_{2}$ のとき，

$$
A_{2}=A_{12}{ }^{*} A_{1}{ }^{+} A_{12} \quad\left(\operatorname{rank} A=\operatorname{rank} A_{1}\right) \quad \text { (13.1) }
$$$$
A_{1}=A_{12} A_{2}{ }^{+} A_{12}{ }^{*} \quad \text { (rank } A=\operatorname{rank} A_{2} \text { ) (13.2) }
$$
が成り立つ

\section{補題 1〜4の証明は付録に示す。}

3.2 修正 Riccati と修正 Lyapunov方程式 制 御対象と補偵器の拡大系を考える（1)，(2)式より 次式が得られる。

$$
\begin{aligned}
& \dot{\bar{x}}=\bar{A} \bar{x}+\bar{B} \bar{w} \\
& \bar{x} \triangleq\left[x^{T} x_{c}{ }^{T}\right]^{T}, \quad \bar{w} \triangleq\left[w_{1}{ }^{T} w_{2}{ }^{T}\right]^{T} \\
& \tilde{A}=\left[\begin{array}{cc}
A & B C_{c} \\
B_{c} C & A_{c}
\end{array}\right], \quad \tilde{B}=\left[\begin{array}{cc}
B_{n} & 0 \\
0 & B_{c}
\end{array}\right]
\end{aligned}
$$

( 3 ) 式の評価コスト $J$ は

$$
\begin{aligned}
& J=\left\{\lim _{r \rightarrow \infty} \frac{1}{T} \int_{0}^{T} \tilde{x}^{T} \tilde{R} \tilde{x} d t\right\}=\operatorname{tr}\{\tilde{Q} \tilde{R}\} \\
& \tilde{Q}=E\left\{\tilde{x} \tilde{x}^{T}\right\}, \quad \tilde{R}=\left[\begin{array}{cc}
C^{T} R_{1} C & 0 \\
0 & C_{c}{ }^{T} R_{2} C_{c}
\end{array}\right]
\end{aligned}
$$

となる. (2)式の低次元補償器は $\tilde{A}$ を安定行列にす るものでなければならないこのとき司は次の Lyapunov 方程式の解である。

$$
\begin{aligned}
& \tilde{A} \tilde{Q}+\tilde{Q} \tilde{A}^{T}+\tilde{W}=0 \\
& \tilde{W}=\left[\begin{array}{cc}
B_{n} W_{1} B_{n}{ }^{T} & 0 \\
0 & B_{c} W_{2} B_{c}{ }^{T}
\end{array}\right]
\end{aligned}
$$$$
W_{1} \triangleq E\left\{w_{1} w_{1}{ }^{\top}\right\}, \quad W_{2} \triangleq E\left\{w_{2} w_{2}{ }^{T}\right\}
$$

さて，(16)式の拘束条件下でJの最小化を静的最 適化法で考える.ラタラランジっ未定乗数を $\tilde{P}(\in$ $Q^{\left(n+n_{c}\right) \times\left(n+n_{c}\right)}$ とし，次のラグランジュ関数 $L$ を定義 する。

$$
L \triangleq J+\operatorname{tr}\left\{\tilde{P}^{T}\left[\bar{A} \bar{Q}+\bar{Q} \bar{A}^{T}+\bar{V}\right]\right\}
$$

最適化の必要条件は $\partial L / \partial \tilde{Q}=0$ より

$$
\bar{A}^{T} \bar{P}+\tilde{P} \bar{A}+\tilde{R}=0
$$

またJは， $A_{c} ， B_{c} ， C_{c}$ についても最適化を考える必 要がある。そこで， $\tilde{Q}, \tilde{P}$ を

$$
\tilde{Q}=\left[\begin{array}{ll}
n & \widetilde{Q}_{c} \\
Q_{12}{ }^{T} & Q_{12}
\end{array}\right] \quad \tilde{P}=\left[\begin{array}{ll}
n & n_{c} \\
\widetilde{P}_{1} & \widetilde{P}_{12} \\
P_{12}{ }^{T} & P_{2}
\end{array}\right]
$$

と分割して $L$ を書き下し， $A_{c}, B_{c}, C_{c}$ についての 微分を行う。

$$
\frac{1}{2}\left(\partial L / \partial A_{c}\right)=P_{12}{ }^{T} Q_{12}+P_{2} Q_{2}=0
$$

$$
\begin{aligned}
\frac{1}{2}\left(\partial L / \partial B_{c}\right)= & P_{2} B_{c} W_{2}+P_{12}^{T} Q_{1} C^{T} \\
& +P_{2} Q_{12}{ }^{T} C^{T}=0 \\
\frac{1}{2}\left(\partial L / \partial C_{c}\right)= & R_{2} C_{c} Q_{2}+B^{T} P_{1} Q_{12} \\
& +B^{T} P_{12} Q_{2}=0
\end{aligned}
$$

修正 Riccati，修正 Lyapunov 方程式は (16)，(18) 式を元として，(19)式の分割された行列成分を用いる ことにより導かれる。まず， $Q_{2} ， P_{2}$ が正定であるこ とを示す (16)式の (2,2)成分は, 補題 4 の(12.2)式 の第 2 式の関係を使って整理すると

$$
\begin{aligned}
& \left(A_{c}+B_{c} C Q_{12} Q_{2}{ }^{+}\right) Q_{2}+Q_{2}\left(A_{c}\right. \\
& \left.\quad+B_{c} C Q_{12} Q_{2}{ }^{+}\right)^{T}+B_{c} W_{2} B_{c}{ }^{T}=0
\end{aligned}
$$

と書ける。仮定により $\left(A_{c}, B_{c}\right)$ は可制御だから $\left(A_{c}\right.$ $\left.+B_{c} C Q_{12} Q_{2}{ }^{+}, B_{c} W_{2}{ }^{1 / 2}\right)$ も可制御。よって $Q_{2}>0$. 同 様に $\left(C_{c}, A_{c}\right)$ は可観測だから $P_{2}>0$.このことから (20)式は

$$
I_{n}=-P_{2}^{-1} P_{12}{ }^{T} Q_{12} Q_{2}{ }^{-1}
$$

と変形できる。そこで補題 $2 ， 3$ を適用するために， $\tilde{Q}, \tilde{P}$ の各成分を次のようにおく。

$$
\begin{aligned}
& G \triangleq Q_{2}{ }^{-1} Q_{12}{ }^{T}, \quad F \triangleq-P_{2}{ }^{-1} P_{12}{ }^{T}, \quad M \triangleq Q_{2} P_{2} \\
& \bar{Q} \triangleq Q_{12} Q_{2}^{-1} Q_{12}{ }^{T}, \quad \bar{P} \triangleq P_{12} P_{2}^{-1} P_{12}{ }^{T} \\
& -Q_{12} Q_{2}{ }^{-1} P_{2}{ }^{-1} P_{12}{ }^{T} \triangleq G^{T} F=\tau\left(\in \mathcal{R}^{T \times n}\right) \\
& \text { これは明らかに } \\
& G^{T} M F=\overline{Q P} \\
& \tau \bar{Q}=\bar{Q}, \quad \bar{P}_{\tau}=\bar{P}
\end{aligned}
$$

を満たす。よって、, $\bar{Q}$ と $\bar{P}$ は反傾変換によって同時 対角化可能であり，rank $\overline{Q P}=n_{c}$ である．さらに

$$
Q \triangleq Q_{1}-\bar{Q}, \quad P \triangleq P_{1}-\bar{P}
$$

を定義すると，(16)，(18)式から次の四つの方程式が 導かれる3.4.

$$
\begin{aligned}
& A Q+Q A^{T}+B_{n} W_{1} B_{n}{ }^{T}-Q \bar{\Sigma} Q \\
& \quad+\tau_{\perp} Q \bar{\Sigma} Q \tau_{\perp}{ }^{T}=0 \\
& A^{T} P+P A+C^{T} R_{1} C-P \Sigma P \\
& \quad+\tau_{\perp}{ }^{T} P \Sigma P \tau_{\perp}=0 \\
& (A-\Sigma P) \bar{Q}+\bar{Q}(A-\Sigma P)^{T} \\
& \quad+Q \bar{\Sigma} Q-\tau_{\perp} Q \bar{\Sigma} Q \tau_{\perp}{ }^{T}=0 \\
& (A-Q \bar{\Sigma})^{T} \bar{P}+\bar{P}(A-Q \bar{\Sigma}) \\
& \quad+P \Sigma P+\tau_{\perp}{ }^{T} P \Sigma P \tau_{\perp}=0 \\
& \Sigma し . \\
& \tau_{\perp}=I_{n}-\tau \\
& \bar{\Sigma}=C^{T} W_{2}{ }^{-1} C, \quad \Sigma=B R_{2}{ }^{-1} B^{T}
\end{aligned}
$$

(28)，(29) 式が修正 Riccati 方程式，(30)，(31)式が 修正 Lyapunov 方程式である。

低次元補傥器の各行列は，(21)，(22)，(24)，(25) 式より

$$
A_{c}=F(A-Q \bar{\Sigma}-\Sigma P) G^{T}
$$




$$
\begin{aligned}
& B_{c}=F Q C^{T} W_{2}^{-1} \\
& C_{c}=-R_{2}^{-1} B^{T} P G^{T}
\end{aligned}
$$

と求められる.

以上のことから，最適射影法に上る低次元補偵器の 構成は (28)〜(31)式を満たす $P, Q ， \bar{Q}, \bar{P}$ を求め， $\bar{Q} ， \bar{P}$ を反傾変換によって同時対角化する正則行列 $T$ から (A.9)，(33)式を使って $A_{c} ， B_{c} ， C_{c}$ を求め ることになる。 $n_{c}=n$ のとき，補題 $2 ， 3$ および(32) 式から明らかなように $\tau_{\perp}=0$ であり，(28)〜(31)式は 非連成化する。このとき（28），(29)式は通常の Riccati 方程式。(30)，(31)式は通常の Lyapunov 方 程式となり，(33)式から計算される補偵器は最適オブ ザーバと一致する。このように，(28)〜(31) 式は評価 コスト $J$ を最小化する条件を補償器の次数が $n$ 次以 下に㹡張したものとみなすことができる．

\section{4. 最適射影法の計算方法}

4.1 Hyland らの計算法の問題点とその対策 最 適射影法による低次元補償器の構成で最も大きな問題 は，如何にして修正 Riccati，修正 Lyapunov 方程式 を解くかである. (28)〜(31)式から明らかなように， 修正 Riccati，修正 Lyapunov 方程式はすべて $\tau_{\perp} を$ 含んだ形で連成している。そのため。これらを同時に 満たす解を一度の計算において求めることは不可能で あり。繰り返し計算による方法を用いなければならな い.

Hyland らはこの解法として，緩和法とホモトピー 法をそれぞれ内ループと外ループに設定した綠返し法 を提案しているい).これらの考え方は，て项を無視 すれば四つの式は独立して解ける。そこで，徐々にこ の項のウエイトを強めていくように調節しょうという ものである。緩和法は， $\overline{Q P}$ のランクを減らしていく ように重み付けを考えているのに対し，ホモトピー法 は $\tau_{\perp}$ の項全体に1より十分小さい正数を掛け，それ を徐々に 1 に近つける。また， $P, Q ， \bar{Q}, \bar{P}$ の初期 值には $\tau_{\perp}=0$ として (28) （31) 式を独立に解いたもの を用いている。

しかしながら、この計算アルコリスムで用いている 緩和法は修正 Lyapunov 方程式を解く際に定数項の 半正定性を破壊することがあり， $\bar{Q}, \bar{P}$ の反傾変換が できなくなり計算の中断を余儀なくされることが起こ クうる.とくに $n_{c}$ が小さく，大幅な $\overline{Q P}$ のランクの 低隇を行うときほどその傾向が強い。このような問題 を回避するために，本研究では緩和法における重み付 けを定数項の半正定性が保たれるように改良した計算 法を提案する.

いま，(28)〜(31)式を満たす半正定行列 $\bar{Q}, \bar{P} か ゙$
求まっているとする。このとき

$$
T^{-1} \overline{Q P} T=\Lambda^{2} \triangleq \operatorname{diag}\left\{\lambda_{1}{ }^{2} \cdots \lambda_{n_{c}}{ }^{2} 0 \cdots 0\right\}
$$

と表される。このとき $\lambda_{\imath}{ }^{2}$ は $\overline{Q P}$ の需でない固有值と 一致し， $\lambda_{i}$ は正である。反倾変換行列 $T$ は

$$
T^{-1} \bar{Q} T^{-1}=T^{T} \bar{P} T=\Lambda
$$

となるようにバランス化されている，Tは $\overline{Q P}$ の固 有ぺクトルを並べて構成されているのではないことに 注意されたい，Tの構成法については文献 7 を参照 されたい。（30)式の左から $T^{-1}$ ，右から $T^{-T}$ を掛 けると

$$
\begin{aligned}
& T^{-1}(A-\Sigma P) T \Lambda \\
& \quad+\Lambda\left\{T^{-1}(A-\Sigma P) T\right\}^{T}+\bar{\Phi}=0 \\
& \bar{\Phi} \triangleq T^{-1}\left(Q \bar{\Sigma} Q-\tau_{\perp} Q \bar{\Sigma} Q \tau_{\perp}{ }^{T}\right) T^{-1}
\end{aligned}
$$

こで

$$
T^{-1} Q \bar{\Sigma} Q T^{-\tau} \triangleq \Phi=\left[\begin{array}{cc}
\Phi_{1} & \Phi_{12} \\
\Phi_{12} T & \Phi_{2}
\end{array}\right](\geqq 0)
$$

とおくと(37)式は

$$
\bar{\Phi}=\left[\begin{array}{ll}
\Phi_{1} & \Phi_{12} \\
\Phi_{12}{ }^{T} & 0
\end{array}\right]
$$

となる。. $\Phi_{12}=0$ ならば $\bar{\emptyset} は$ 半正定であるがこれは一 般には成立しない，しかし，解 $\Lambda$ は半正定であるこ

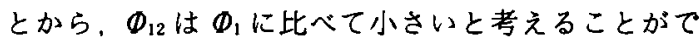
きる.著者が文献 4 で述べられている緩和法によって 作成した計算アルゴリズムでは，この傾向が観察され ている。しかしながら、フルランクの $\bar{Q}, \bar{P}$ からラ ンク $n_{\mathrm{c}}(\leqq n)$ 一低下させる絽り返し計算過程におい

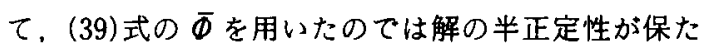
れる保証がない。そこで，市の代わりに次に示す $\bar{\Phi}$ を用いる。

$$
\begin{aligned}
& \hat{\Phi} \triangleq\left[\begin{array}{cc}
I_{n_{c}} & 0 \\
0 & \Lambda_{W}
\end{array}\right] \Phi\left[\begin{array}{cc}
I_{n_{c}} & 0 \\
0 & \Lambda_{W}
\end{array}\right] \\
& \Lambda_{W} \triangleq \operatorname{diag}\left\{\delta_{1} \cdots \delta_{n-n_{c}}\right\} \quad 0 \leqq \delta_{t} \leqq 1
\end{aligned}
$$

$\delta_{1}$ は非負なので $\Lambda_{w}$ は半正定，またのは半正定なの ですは常に半正定となる（31)式に対しても同様な ことがいえる。

$$
T^{\tau} P \Sigma P T \triangleq \Psi=\left[\begin{array}{cc}
\Psi_{1} & \Psi_{12} \\
\Psi_{12}{ }^{\top} & \Psi_{2}
\end{array}\right](\geqq 0)
$$

とすれば

$$
\bar{\Psi} \triangleq\left[\begin{array}{cc}
I_{n_{c}} & 0 \\
0 & \Lambda_{W}
\end{array}\right] \Psi\left[\begin{array}{cc}
I_{n_{c}} & 0 \\
0 & \Lambda_{W}
\end{array}\right]
$$

を(31)式の定数項として用いる.よって, 修正 Lyapunov 方程式の解 $\bar{Q}, \bar{P}$ は常に半正定行列とな る。なお，繰り返し計算では， $\delta_{i}=\lambda_{n_{c}+i} / \lambda_{n_{c}}$ とするこ とにより、徐々に0に近づける操作が施されている。 このことにより， $\bar{Q} ， \bar{P}$ のランクをそれぞれ低隇する ことができる．その具体的な計算アルゴリスムを次節 です. 
4.2 計算アルゴリスム 前節に述べた考え方に 沿って，低次元補償器構成の計算アルゴリスムを示 す. $k$ は繰り返し回数を表し $\varepsilon$ はランク判定の敷居值 とする ( $\varepsilon$ 以下ならばランク落ちを意味する).

Step 1： $n_{c}$ を設定する. $k=1$. ただし， $\tau_{\perp}(1)=0$, $T(0)=I_{n}$.

Step 2: 修正 Riccati，修正 Lyapunov 方程式を解 $<$.

$$
\begin{aligned}
& A Q(k)+Q(k) A^{T}+B_{n} W_{1} B_{n}{ }^{T}-Q(k) \bar{\Sigma} Q(k) \\
& \quad+\tau_{\perp}(k) Q(k) \bar{\Sigma} Q(k) \tau_{\perp}(k)^{T}=0 \\
& A^{T} P(k)+P(k) A+C^{T} R_{1} C-P(k) \Sigma P(k) \\
& \quad+\tau_{\perp}(k)^{T} P(k) \Sigma P(k) \tau_{\perp}(k)=0 \\
& (A-\Sigma P(k)) \bar{Q}(k)+\bar{Q}(k)(A-\Sigma P(k))^{T} \\
& \quad+T(k-1) \bar{\Phi}(k) T(k-1)^{T}=0 \\
& (A-Q(k) \bar{\Sigma})^{T} \bar{P}(k)+\bar{P}(k)(A-Q(k) \bar{\Sigma}) \\
& \quad+T(k-1)^{-T} \hat{\Psi}(k) T(k-1)^{-1}=0 \\
& \quad \\
& \bar{\Phi}(1)=Q(1) \bar{\Sigma} Q(1), \quad \hat{\Psi}(1)=P(1) \Sigma P(1)
\end{aligned}
$$
ただし，

Step 3 : 反傾変換行列 $T(k)$ を次のようにバランス 化させて求める。

$$
\begin{aligned}
& T(k)^{-1} \bar{Q}(k) T(k)^{-T}=T(k)^{T} \bar{P}(k) T(k) \\
& \quad=\Lambda(k)=\operatorname{diag}\left\{\lambda_{1}(k) \cdots \lambda_{n}(k)\right\} \\
& \lambda_{1}(k) \geqq \lambda_{2}(k) \geqq \cdots \geqq \lambda_{n}(k) \\
& \tau_{\perp}(k)=T(k) \operatorname{diag}\{0 \cdots 0 \quad 1 \cdots 1\} T(k)^{-1}
\end{aligned}
$$

Step $4: k>1$ のとき

$$
\lambda_{n_{c}+1}(k) / \lambda_{n_{c}}(k) \leqq \varepsilon
$$

ならば Step 6 へ，それ以外は Step 5.

Step $5: \bar{\Phi}(k), \bar{\Psi}(k)$ を計算する.

$$
\begin{aligned}
& \Lambda_{w}(k)=\operatorname{diag}\left\{\delta_{1}(k) \cdots \delta_{n-n_{c}}(k)\right\} \\
& \delta_{i}(k)=\lambda_{n_{c}+i}(k) / \lambda_{n_{c}}(k) \quad i=1, \cdots, n-n_{c} \\
& \tilde{\Phi}(k+1)=\left[\begin{array}{cc}
I_{n_{c}} & 0 \\
0 & \Lambda_{W}(k)
\end{array}\right] \Phi(k)\left[\begin{array}{cc}
I_{n_{c}} & 0 \\
0 & \Lambda_{W}(k)
\end{array}\right] \\
& \hat{\Psi}(k+1)=\left[\begin{array}{cc}
I_{n_{c}} & 0 \\
0 & \Lambda_{W}(k)
\end{array}\right] \Psi(k)\left[\begin{array}{cc}
I_{n_{c}} & 0 \\
0 & \Lambda_{W}(k)
\end{array}\right]
\end{aligned}
$$

$k=k+1$ として. Step $2 へ$.

Step 6 : 低次元補償器を求める.

$$
\begin{aligned}
& G=\left[\begin{array}{ll}
I_{n_{c}} & 0
\end{array}\right] T(k)^{T}, \quad F=\left[\begin{array}{ll}
I_{n_{c}} & 0
\end{array}\right] T(k)^{-1} \\
& A_{c}=F(A-Q(k) \bar{\Sigma}-\Sigma P(k)) G^{T} \\
& B_{c}=F Q(k) C^{T} W_{2}^{-1} \\
& C_{c}=-R_{2}^{-1} B^{T} P(k) G^{T}
\end{aligned}
$$

Step 2 の修正 Riccati 方程式は，Kleinmanの方 法息を適用して解く. Step 3 で行っているバランス化 は、補償器の各モードの入出力量を同じレヘルにする ための操作である．またそれを大きい順に並べること により，下位のモードほど入出力全体に奇与する度合 が相対的に低いことを意味している．すなわち，可制
第 1 表 数値計算ケース

\begin{tabular}{cccc}
\hline Case & Output $y$ & $R_{1}$ & $R_{2}$ \\
\hline 1 & $h$ & 1 & 1 \\
2 & $\ddot{h}$ & $10^{-8}$ & 1 \\
3 & {$[h \ddot{h}]^{T}$} & $\operatorname{diag}\left\{110^{-6}\right\}$ & 1 \\
\hline
\end{tabular}

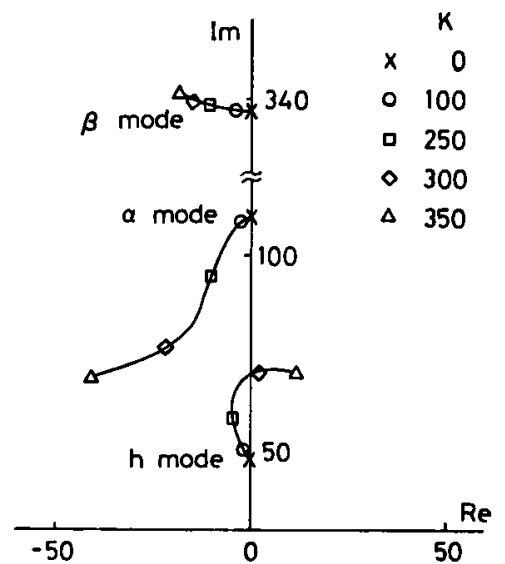

第 2 図 自由流速度の変化による二次元置の特性根

御，可観測性が弱い Step 5では、これらのモード のうち $n-n_{c}$ 個を補償器から削除するように修正 Lyapunov 方程式の定数項に重み付けしている.

\section{AFS システムの数值計算例}

AFS システムのパラメータ値は文献 2 と同じ数値 を用い，第 1 表に示す出力変数とそれに対応する評価 コストの重みについて計算を行う. 第 1 図に示されて いる二次元買の無次元化した自由流速度 $K \triangleq(U / b) の$ 変化に対する特性根の挙動を，第 2 図に示す。フラッ 夕速度は $K_{\mathrm{F}}=297.13$ である。制御系設計の設計点は， 1 割程度のフラッタ速度の增加を目標にして約 $9.4 \%$ 高い $K=325$ とする。

第 3 図に得られた低次元補償器によって構成される 制御系の性能評価を示す. $n_{c}=13$ は最適オブザーバ を意味する。ゲイン余裕 ( ( d ) 図)，位相余裕 ((e)図) は系の安定性に関する尺度であり，これが大きいほど フラッタに対してロバストである。よって、これらの 值はフラッタ速度の増加率 ( $(\mathrm{f})$ 図) に強く影篅して いる。なお，この制御対象は第 2 図に示されているよ うに設計点では不安定であるのて，安定余裕は十側 と一側がある。

どのケースも2 次以上の補暴器が構成可能である. しかし，次数低隇に伴うコストの変化 ((a)図) は 5 次以下の低次において必ずしも単調非隇少てなく，局 所的な最小解 (local minimum) に収束してしまって 


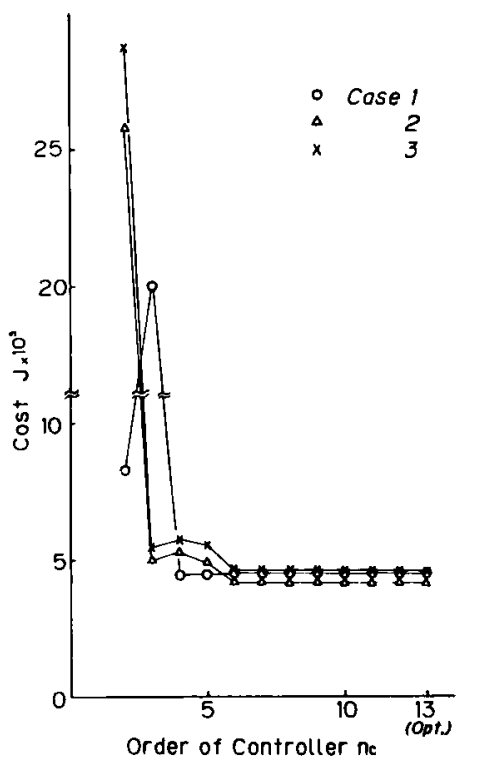

(a) 評価コスト

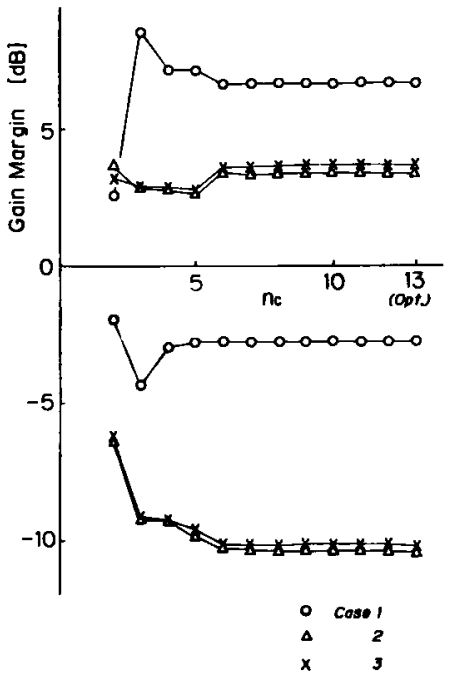

(d) ゲイン余裕

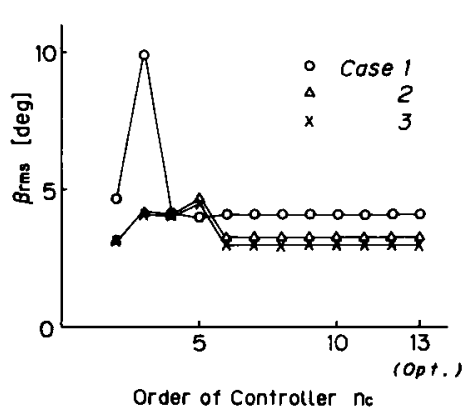

(b) 操舵角量

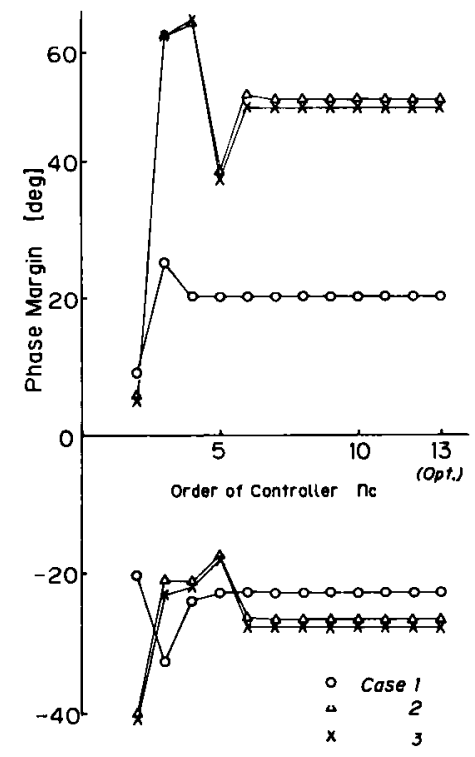

(e) 位相余裕

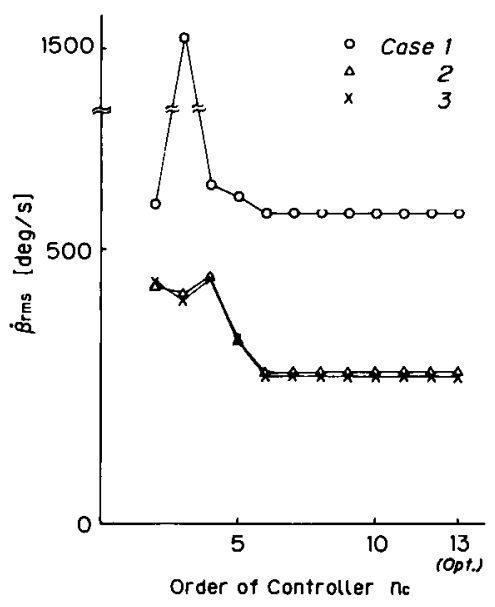

(c) 操舵角速度量

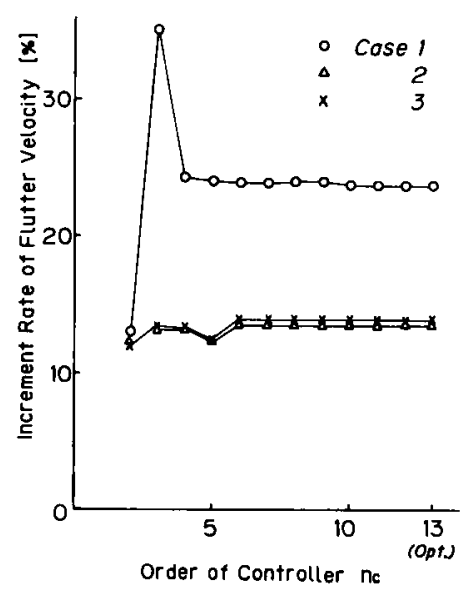

(f) フラッ夕速度の増加害

第 3 図最道射影法で棈成した補供器による制御系性能

いると考えられる. 翼の垂直変位を出力変数として低 次元補償器の棈成を考えたケース 1 において， $n_{c}=2$ の補償器の性能は安定余裕，コストとも他の次数の補 償器よりも悪化している， $n_{c}=3$ ては，コスト．操舵 量が少っている半面, 安定余裕が大きいためフラッタ 速度の増加率は全ての補侻器の中で最高值を示してい る. $n_{c}=4$ 以上では，コストおよびフラッタ速度の増
加率はほほ最適値 $\left(n_{c}=13\right)$ に等しく， $n_{c}=6$ 以上で全 ての性能值が最適值に収束している. 垂直加速度を出 力変数としたケース 2 および 2 出力の場合のケース 3 は，值の変動状況は異なるもののケース 1 と同様な傾 向を示している，このことから，補憒器の次数が 5 次 以下では次数の不足による性能劣化が発生するが，6 次以上であれば 13 次の最適オブザーバと同等の補償 
第 2 表 GHR 法で棈成した補償器による制御系性能

\begin{tabular}{|c|c|c|c|c|c|}
\hline Case & $n_{c}$ & $\begin{array}{l}\text { Gain M. } \\
\text { (dB) }\end{array}$ & $\begin{array}{c}\text { Phase M. } \\
\text { (deg) }\end{array}$ & $\begin{array}{c}\beta_{\mathrm{rms}}(\mathrm{deg}) \\
\dot{\beta}_{\mathrm{rms}}(\mathrm{deg} / \mathrm{s})\end{array}$ & $\begin{array}{c}\text { Cost } \\
J \times 10^{3}\end{array}$ \\
\hline \multirow{6}{*}{1} & \multirow[t]{2}{*}{2} & -6.224 & -6.6 & 7.200 & \multirow[t]{2}{*}{14.8586} \\
\hline & & +1.219 & +4.9 & 716.4 & \\
\hline & \multirow[t]{2}{*}{3} & -6.690 & -4.2 & 10.71 & \multirow[t]{2}{*}{31.1874} \\
\hline & & +0.3834 & +2.0 & 930.2 & \\
\hline & \multirow[t]{2}{*}{7} & -3.024 & -22.4 & 4.096 & \multirow[t]{2}{*}{4.48779} \\
\hline & & +6.069 & +22.5 & 565.5 & \\
\hline \multirow{4}{*}{2} & \multirow[t]{2}{*}{8} & -9.591 & -37.0 & 4.659 & \multirow[t]{2}{*}{4.89225} \\
\hline & & +1.559 & +49.2 & 299.8 & \\
\hline & \multirow[t]{2}{*}{9} & -10.04 & -20.4 & 3.322 & \multirow[t]{2}{*}{4.26864} \\
\hline & & +1.430 & +50.0 & 275.5 & \\
\hline \multirow{6}{*}{3} & \multirow[t]{2}{*}{7} & -9.384 & -2.6 & 16.12 & \multirow[t]{2}{*}{22.9880} \\
\hline & & +0.1587 & +28.9 & 581.8 & \\
\hline & \multirow[t]{2}{*}{8} & -8.692 & -14.9 & 5.811 & \multirow[t]{2}{*}{6.68781} \\
\hline & & +0.8509 & +38.0 & 310.7 & \\
\hline & \multirow[t]{2}{*}{9} & -8.993 & -38.0 & 2.978 & \multirow[t]{2}{*}{4.53036} \\
\hline & & +3.022 & +41.0 & 267.3 & \\
\hline
\end{tabular}

* 低次元近似法 Case 1: トランケーション法, Case 2： ノルム最小化法, Case 3:特異搷動法

第 3 表 NFA 法て構成した補偵器による制御系性能

\begin{tabular}{ccccccc}
\hline Case & $n_{\mathrm{c}}$ & $\begin{array}{c}\text { Gain M. } \\
\text { (dB) }\end{array}$ & $\begin{array}{c}\text { Phase } \mathrm{M} . \\
(\mathrm{deg})\end{array}$ & $\begin{array}{c}\beta_{\mathrm{mms}}(\mathrm{deg}) \\
\beta_{\mathrm{rms}}(\mathrm{deg} / \mathrm{s})\end{array}$ & $\begin{array}{c}\text { Cost } \\
j \times 10^{3}\end{array}$ & $\begin{array}{c}\text { Increment rate of } \\
\text { flutter velocity }(\%)\end{array}$ \\
\hline & 2 & -7.601 & -28.0 & 10.34 & 19.9090 & 32.90 \\
& & +5.120 & +23.4 & 1688 & & \\
& 4 & -6.569 & -44.4 & 21.66 & 90.5935 & 32.78 \\
& & +7.191 & +36.8 & 867.4 & & \\
& 6 & -7.959 & -45.0 & 31.07 & 234.858 & 27.80 \\
& & +7.108 & +36.0 & 8535 & & \\
\hline \multirow{2}{*}{2} & 2 & -5.345 & -24.0 & 2.153 & 18.4421 & 25.88 \\
& & +6.716 & +24.2 & 424.6 & & \\
\hline \multirow{3}{*}{3} & 2 & -4.064 & -27.1 & 8.475 & 14.7816 & 34.10 \\
& & +10.51 & +25.8 & 2035 & & \\
\hline
\end{tabular}

器となるといえる.

出力変数についての比較をすると、ケース 1 のフラ ッ夕速度の增加率はヶース $2 ， 3$ よりも約 $10 \%$ 高い， これは、ケース 1 はケース $2 ， 3$ に比べ操舵量が大き く，とくに $\dot{\beta}_{\mathrm{rms}}$ が 2 倍になっているためである。ま た，ケース 3 はケース 2 と比べ，わずかな差ではある が操舵量が少ないのにフラッ夕速度の增加率が高く， 2 出力であることの優位さを示している，さらに，ヶ 一ス1の位相余裕は十側，一側ともほほ等しいのに対 し，ケース $2 ， 3$ は+側が大きい.ゲイン余裕は, ケ 一ス 1 は+側がー側よりも大きいのに対しケース 2 ， 3では逆になっている．すなわち，周波数特性からみ ると十側のゲイン余裕を大きくしたほうがフラッタに 対してロバストになるといえる。このことは，NFA
法による低次元補償器の構成においても示されてい $3^{2)}$

第 $2 ， 3$ 表に，文献 2 で示されているGHR 法と NFA 法の結果の一部を示す，GHR 法では，ヶース $2 ， 3$ で構成できる低次元補哄器の最低次数はそれぞ れ 8 次， 7 次，ケース1では 2 次の補償器が可能であ るが大幅な性能の劣化が観察され，最適射影法のほう が優れた低次元補償器構成法であるといえる。

NFA 法と比べると，安定余裕やフラッ夕速度の增 加率に関してはNFA 法で構成された低次元補償器の

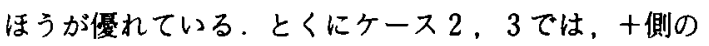
ゲイン余裕の増加を考慮した低次元補偵器設計がなさ れ、フラッタ速度を高めている。しかし，NFA 法は 多入力系への適用が困難である。また，評価コストや 操舵量への考慮がないため，安定余裕を増やした代償 としてこれらの值の増大化を招く傾向がある.したが って，多入力系にも適用可能でかつ評価コストの最小 化を考慮している最適射影法のほうが，より一般性の 高い方法であると思われる。

\section{6. 結論}

本論文は，能動フラッ夕抑止 (AFS) システムに対 する低次元補偵器の構成を最適射影法によって検討 し、新しい計算アルゴリスムを提案するとともに GHR 法, NFA 法との比較を行った。 その結果，以 下のような結論が得られる。

（1）最適射影法において誘導された四つの条件 式，修正 Riccati，修正 Lyapunov 方程式を満たす解 を求めることにより，二次形式評価コストの最小化を 考慮したプラントの次数以下の補償器が構成可能であ る.

（2）本論文で提案された計算アルゴリスムは，修 正 Lyapunov 方程式の解が常に半正定となることを 保証するものであり，解のランクを削除する繰返し計 算において有効な方法である。

（3）最適射影法を使って構成された 13 次の二次 元翼 AFS システムに対する補償器は，2 次以上で系 を安定化することが可能であり．6次以上で最適オブ ザーバと同等な制御性能を持つ補償器になる。

（4）最適射影法は，最適オブザーバを近似して求 める GHR 法よりも低次元で制御性能の良い補償器が 構成可能である。また，制御精度や操舵量を設計仕様 に盛り込んでいる点でNFA 法よりも優れている.

最適射影法は，ここで扱った AFS システムの低次 元補偵器設計以外にも，高次元系となる制御対象には 有用な設計法であると思われる，なお，今回考えた補 償器は（2）式で示された䖝的補哄器であったが，ダイ 
レクトリンクを有する出力フィードバックを考虑した 場合や，外除去や non-zero set point レギュレーショ ン問題に対する低次元補償器の構成に関する計算アル ゴリスムの構成, さらに大域的最小解 (global minimum）を得るための工夫などが今後の研究課題であ る.

最後に、有益な御助言を頂きました校閲者に心より 感謝致します。

\section{参考文献}

1) 片山鉄太郎：ACTによるフラッタ对策の現状，日本航空 宇宙学会誌, 32 (1984)，pp.383-393.

2) 藤森 篤、太田裕文：能動フラッ夕制御に対する低次元コ ントローラの樓成，日本航空宇宙学会誌，35（1987）。 pp. 353-362.

3) Hyland, D. C. and Bernstein, D. S.: The Optimal Projection Equations for Fixed-Order Dynamic Compensation, IEEE Trans. Automat. Control, AC-29 (1984), pp. 10341037.

4) Greeley, S. W. and Hyland, D. C. : Reduced-Order Compensation : Linear-Quadratic Reduction Versus Optimal Projection, J. Guid. Control Dynam. 11 (1988), pp. 328335.

5) Yousuff, A. and Skelton, R. E. : Controller Reduction by Component Cost Analysis, IEEE Trans. Automat. Con trol, AC-29 (1984), pp. 520-530.

6）宮沢予和：最低次数フィルタによるフィードバック制御と 航空機の㔖風荷重軽减装置への応用，計測自動制御学会論 文集. 22 (1986), pp.652-658.

7) Rao, C.R. and Mitra, S.K.: Generalized Inverse of Matrices and Its Applications, John Wiley, New York, 1971.

8) Kleinman, D. C. : On an Iterative Technique for Riccati Equation Computation, IEEE Trans. Automat. Control, AC-13 (1968), pp. 114-115.

9）児玉慎三，須田信英：システム制御のためのマトリクス理 論、計測自動制御学会、1978.

付 録

(補題 1 の証明) $A, B$ のランクを $r_{A}, r_{B}$ とする と，最大階数を持つ行列 $U \in \mathbb{R}^{n \times r_{A}}, V \in \mathbb{R}^{n \times r_{B}}$ によ ってそれぞれ

$$
A=U U^{T}, B=V V^{T}
$$

と分解できる．ここで $\operatorname{rank} U^{T} V \triangleq r\left(\leqq \min \left(r_{A}, r_{B}\right)\right)$ とおくと, $U^{T} V V^{T}\left(=U^{T} B\right)$ のランクはシルベスタ
一の不等式より

$r+r_{B}-r_{B} \leqq \operatorname{rank} U^{T} B \leqq \min \left(r, r_{B}\right)=r$

$\therefore \operatorname{rank} U^{\top} B=r$

さらに, $U U^{T} B(=A B)$ のランクは

$r_{A}+r-r_{A} \leqq \operatorname{rank} A B \leqq \min \left(r_{A}, r\right)=r$

$\therefore \operatorname{rank} A B=r$

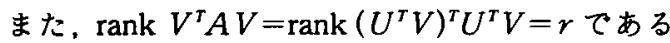
から， $V V^{\top} A V V^{\top}(=B A B)$ のランクを上の議論と 同様に考えると， $\operatorname{rank} B A B=r$ むえに，

rank $A B=\operatorname{rank} B A B$

これは文献 7 の定理 6.2 .4 で示されている反傾変換可 能条件であり、よって

$$
\begin{aligned}
& T^{-1} A T^{-*}=\Lambda_{A}(\geqq 0) \\
& T^{*} B T=\Lambda_{B}(\geqq 0)
\end{aligned}
$$

上式より

$$
\begin{aligned}
\Lambda \triangleq \Lambda_{A} \Lambda_{B} & =T^{-1} A B T \\
& =\Lambda_{B} \Lambda_{A}=T^{*} B A T^{-*}(\geqq 0)
\end{aligned}
$$

となるから $A B$ または $B A$ は正の半単純行列である.

（補題 2 の証明） 補題 $1 の(A .4)$ 式より

$$
A=T \Lambda_{A} T^{T}, \quad B=T^{-T} \Lambda_{B} T^{-1}
$$
ただし， $\Lambda_{A}, \Lambda_{B}$ の対角要素において，初めの $r$ 個は

0でない正数となるように分解する。

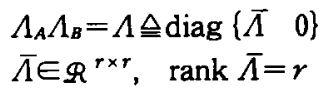

と表せるから

$$
A B=T \Lambda_{A} \Lambda_{B} T^{-1}=T\left[\begin{array}{c}
I_{r} \\
0
\end{array}\right] \bar{\Lambda}\left[\begin{array}{ll}
I_{r} & 0
\end{array}\right] T^{-1}
$$

よって

$$
G \triangleq\left[\begin{array}{ll}
I_{r} & 0
\end{array}\right] T^{T}, \quad F \triangleq\left[\begin{array}{ll}
I_{r} & 0
\end{array}\right] T^{-1},
$$$$
M \triangleq \bar{\Lambda}
$$

とすると $(7) ，(8)$ 式が满たされる。

（補題 3 の証明）(A.6)，(A.9)式より明らか.

(補題 4 の証明) 文献 9,pp.328-329に扔いて示 されている，ただし、(12)，(13)式は疑似逆行列で表 現している（疑似逆行列は一般化逆行列に属するので 問題ない)。また，(12.1)，(13.1)式は(12.2)。 (13.2)式と同様に証明できる。 